„Bohemistyka” 2019, nr 3, ISSN 1642-9893

Anna GAWARECKA

DOI: $10.14746 /$ bo.2019.3.2

Uniwersytet im. Adama Mickiewicza

\section{Instynkt samozachowawczy czy zdrada idealów. Czeska literatura wobec etycznych dylematów epoki późnego komunizmu}

Keywords: ethical message of literature, normalization, posttotalitarism, literary intrigue, moral nihilism

Słowa kluczowe: etyczne przesłanie literatury, normalizacja, posttotalitaryzm, literacka intryga, amoralizm

\section{Summary}

The eminent Czech writers of the the second half of the twentieth century, for example Václav Havel, Zdeněk Zapletal, Vladimír Macura or Ivan Vyskočil, tried in their works to show the ethical problems connected with the introducing the communist system (especially in its late phase, known as the „time of normalization”) and its influence on the human identity leading to call in guestion the paradigma of traditional values. They search the way to explore the state of the modern mind and they find it in the alienation and disintegration of personality caused by deformation of understanding these values which is perceived as the consequence of the disturbed ralation between the assumptions and directives of the communist ideology an the empirical reality of the political and social life.

Najważniejsi czescy pisarze drugiej połowy XX wieku, między innymi Václav Havel, Zdeněk Zapletal, Vladimír Macura czy Ivan Vyskočil, próbowali w swoich dziełach pokazać problemy aksjologiczne związane z wprowadzeniem systemu komunistycznego (zwłaszcza w jego późnej fazie, określanej jako „epoka normalizacji”) i zdiagnozować jego destrukcyjny wpływ na ludzką tożsamość, odwołując się przede wszystkim do ulegającego procesom rozkładowym paradygmatu tradycyjnych wartości. Szukają sposobu na zbadanie stanu współczesnego umysłu i odnajduja go w alienacji i dezintegracji osobowości spowodowanej deformacją rozumienia dzy założeniami i dyrektywami ideologii komunistycznej a doświadczaną rzeczywistością życia politycznego i społecznego.
Napadlo vás někdy, že bychom ani ten nejprostší mravní čin, který nelze vyložit nějakými účelovými ohledy, vůbec nepochopili, ba co víc, musel by se nám jevit jako zcela absurdní, kdybychom si nepřiznali, že kdesi v jeho nejvnitřnějších útrobách je zaklet předpoklad čehosi nad námi, nějaké absolutní, vševedoucí a nekonečně spravedlivé instance či mravní autority, skrze níž a v níž se všechno naše počínání nějak záhadně zhodnocuje a jejímž prostřednictvím se každý z nás dotýká věčnosti?

$$
\text { (Havel 1992, s. 391) }
$$

Pytanie to, aczkolwiek w tekście dramatu Václava Havla Pokoušení (1985) pełni funcję stricte instrumentalną, stanowi bowiem element strategii erotycznego uwodzenia, otwiera jednocześnie drogę ku rudymentarnym rozważaniom rozpatrujacym problem obiektywnego istnienia wartości oraz poszukującym dla nich uzasadnienia $\mathrm{w}$ przestrzeni transcendencji, której ontologiczna realność, choć jedynie hipotetycznie zakładana, w ostatecznym rozrachunku gwarantuje owym wartościom sens, trwanie oraz charakter niepodważalnego aksjomatu. W koncypowanej na zasadzie intertekstualnej gry z podstawowymi wątkami pierwszej części Fausta Goethego Havlowskiej grotesce historia zawarcia paktu z Szatanem przeradza się nie tyle w traktat o ontologii Absolutu, ile w moralitet opowiadajacy o swoistej ,etyce zdrady”, w którym naukowiec i wielbiciel okultyzmu, Foustka, za pomoca rytuałów magicznych wywołuje „zdegradowanego diabła" Fistulę, ten zaś, sięgając po repertuar sofistycznych argumentów, przekonuje protagoniste, że

Přečetl jste toho přece dost, a musíte tedy vědět, že i v našich sférách jsou meze, které nelze překročit. [...] Copak nechápete, že jsme-li schopni si zahrávat s celým světem, pak jen a jen proto, že se opíráme o kontakty, s nimiž si zahrávat prostě nelze? Obelhávat lháře je dobré, obelhávat pravdomluvného je př́pustné, ale obelhávat intanci, která nám $\mathrm{k}$ tomuto obelhávání dává sílu a předem nás $\mathrm{v}$ této věci vybavuje beztrestností - to věru už beztrestně nejde! Tamten (ukaže nahoru) zahrnuje člověka množstvím nedodržitelných př́kazů a nezbyvá mu tudíž, než občas odpouštět. Jin naopak člověka od všech těch neudržitelných příkazů osvobozují, dík čemu jsou pochopitelně i zcela zbaveni nutnosti, př́ležitosti a posléze vưbec schopnost 
odpouštět. Ale i kdyby toho nebylo, zradu dohody, která všechnu tu bezbřehou svobodu otevírá, by stejně odpustit nemohli: vždyt takovým odpouštěním by se zbořil celý jejich svět! Anebo není snad jedinou zárukou svobody od všech závazků závazek věrnosti autoritě, která nám takovou svobodu dává? (Havel 1992, s. 422).

Wprowadzenie figury ,jarmarcznego Mefistofelesa”, przywodzącej na myśl, jak dowodzi Martin C. Putna (por. Putna 2011, s. 230), raczej renesenasowe, nierzadko przeznaczone dla ludowego odbiorcy, opowieści o Fauście niż ich Goethowską pogłębioną filozoficzną reinterpretację, pozwala - na poziomie uniwersalnej generalizacji - na sformułowanie tezy, że zło rodzi się w człowieku, a zatem stanowi niezbywalną antropologiczną konstantę, która wszelkie transcendentne epifanie, na przykład osobowe inkarnacje Szatana, postrzega w kategoriach fatalistycznego usprawiedliwienia indywidualnych etycznych upadków:

Pochopte to přece: jsem jen katalyzátor, který svým bližním pomáhá probudit či urychlit to, co v nich už dávno i bez něj je či probíhá! Dík této mé pomoci mohou pak objevit v sobě odvahu něco vzrušujícího v životě prožít a užít a stát se tak plněji, pravdivěji a bohatěji sami sebou. [...] Víte, proč jste mě nazval d'áblem? Abyste svou odpovědnost lokalizoval - ze samého strachu ze svých skrupulí a z toho ve vás, co je lame - kamsi vně, mimo své já, $v$ daném případě do mně a tímto - jak vy vědci ř́íkate „přenosem” či „projekcí” si usnadnil život! (Havel 1992, s. 406).

Moment powstania dramatu - połowa lat osiemdziesiątych - zmusza jednak do poszukiwania innych, bardziej skonkretyzowanych i być może podddanych procesom znaczeniowej symplifikacji sensów dokonanej przez Havla parafrazy faustowskich dylematów. Zarówno osobista sytuacja autora, którego twórczość objẹta była wówczas całkowitym zakazem cenzury, jak i jego wcześniejsze wypowiedzi publicystyczne i literackie, jednoznacznie poświęcone problemom społecznych i politycznych deformacji życia w ustroju socjalistycznym, nakazują bowiem odczytywać przesłanie dzieła w ściśle określonych ramach polemiki z „demonicznymi” aspektami systemu, gdyż, co podkreśla Putna,

[...] d’ábel je vpravdě dokonalým podobenstvím o moci komunistického režimu moci nabízející iluzorní dobra a přitom vždy podvádějící a ničící (Putna 2011, s. 230).
Destrukcyjność ta dotyczy zaś przede wszystkim przestrzeni wyborów aksjologicznych, poddanej silnej, choć w końcowym okresie istnienia socjalistycznego państwa w Foucaultowskim rozumieniu rozproszonej, kontroli, wymagającej całkowitego podporządkowania się a priori wyznaczonym regułom gry ${ }^{1}$.

Reguły te, wypracowane w sferze praw niepisanych co prawda, ale w realny sposób określających style funkcjonowania życia codziennego, stanowiły nieoczekiwany i zapewne dla kodyfikatorów oficjalnej polityki zaskakujący rezultat neostalinowskich procesów, koncypowanych jako odpowiedź na liberalizacyjne tendencje z lat sześćdziesiątych. W grudniu 1970 roku Komitet Centralny Komunistycznej Partii Czechosłowacji ogłosił dokument zatytułowany Poučení z krizového vývoje ve straně a společnosti, oficjalnie proklamujący okres tzw. normalizacji, która zgodnie z najważniejszymi konkluzjami uchwały polegać miała na „uporządkowaniu” panujących w kraju relacji na bazie marksizmu-leninizmu. By ten porządek zbudować czy raczej odnowić należało przede wszystkim

[...] zformovat všechny zdravé síly ve straně i mimo stranu k rozhodnému úderu proti reakci, odhalit pravicové oportunisty a jejich skutečné záměry, porazit pravici v otevřeném politickém boji, vyrvat ji z rukou rozhodující mocenské pozice a nástroje, zejména sdělovací prostředky, a vymanit široké vrstvy pracujících $\mathrm{z}$ jejího vlivu.

\footnotetext{
${ }^{1}$ Havel w innym miejscu dowodzi, że traktowanie relacji aparatu państwowego ze społeczeństwem w kategoriach gry, a zatem, jak to dramatopisarz określa, „dyktat rytuału” „sprawia [...], że władza wyraźnie nabiera charakteru anonimowego. Człowiek roztapia się niemal w rytuale, daje mu się unosić - i częstokroć zdaje się, że to sam rytuał wydobywa ludzi z mroku na światło władzy: bo też czy dla systemu posttotalitarnego nie jest typowe, że na wszystkich szczeblach hierarchi władzy indywidualności są coraz to bardziej wypierane przez ludzi bez oblicza, marionetki, zuniformizowane sługi rytuału i rutyny? Samoczynny ruch odczłowieczonej i zanonimizowanej w ten sposób władzy jest jednym z parametrów owego podstawowego »samoruchu« systemu; odnosi się wrażenie, iż dyktat tego »samoruchu sam powołuje do władzy ludzi bez indywidualnej woli, że ten «dylemat frazesu» sam dobiera do władzy »ludzi frazesu«, jako najlepszych gwarantów »samoruchu« systemu posttotalitarnego" (Havel 2001, s. 80).
} 
Přitom podmínky, v nichž se tento zápas odehrával, byly mimořádně těžké a složité (Poučení 1970, s. 36)

Innymi słowy, i w tym tkwi przewrotność, czy jakby to określił Mirosław Karwat, perfidia użytego w tym kontekście określenia „,normalizacja", jego twórcy sugerują oczywistość narzucanych społeczeństwu przemian i za ,wynaturzone" uznają zainicjowane w odwilżowej dekadzie pluralistyczne (wspólnotowe i indywidualne) dążenia i ambicje $^{2}$. Odbierając prawo do wyboru światopoglądowych wiar i przekonań i de facto likwidując horyzont metafizyczny, komunistyczny reżim zaproponował w zamian szczególny konglomerat ideologicznych haseł, w którym pojęcia dobra i zła, zatracając swą wyrazistą antynomiczność, zyskały sankcję pragmatyczną i uzależniły waloryzację zachowań od ich przydatności dla podtrzymywania i legitymizacji panującego układu sił politycznych. Dodatkowo, w ,znormalizowanych" latach siedemdziesiątych i osiemdziesiątych, imperatyw autentycznego zaangażowania zastąpiła swoista gra, w której ,uczestnicy”, sięgając po znany wszystkim repertuar ustalonych gestów, rytuałów i całkowicie pod względem znaczeniowym spetryfikowanych haseł, udają, choć z różnych powodów, akceptację i - co istotniejsze wiarę w słuszność, a tym samym: niezmienność systemowych roz-

${ }^{2}$ Badacz definiuje perfidię jako „takie działanie praktyczne, które opiera się na przewrotnej komunikacji. Ta destrukcyjna przewrotność to osiąganie zamierzonych rezultatów cudzym kosztem poprzez postępowanie zaprzeczające wzbudzonym oczekiwaniom lub wręcz działanie na cudzą szkodę, któremu towarzyszy przepyszna gra pozorów, sugestia postrzegania sytuacji dokładnie przeciwstawnego realiom (wróg w roli przyjaciela, złodziej w roli stróża porządku i własności, kłamca i oszczerca jako obrońca wolności słowa i prawdy itd., itp.). Podstawą do tego jest wykorzystanie dwuznaczności gestów, słów, wypowiedzi i zachowań. Ta wieloznaczność umożliwia - w dogodnym, wybranym momencie - odwracanie formalnego (rytualnego, umownego) sensu wypowiedzi i czynności, zaskakujące zaprzeczenie wywołanym złudzeniom. [...] Perfidia jest więc [...] destrukcyjna odmiana przewrotności. Dokładniej mówiąc: destrukcyjną formą przewrotności praktycznej (użytkowej), tzn. takiej, która powoduje trwałe, zmaterializowane, przynajmniej cześciowo nieodwracalne skutki (szkody i cierpienia ofiary), przynosi przy tym korzyści takiego «obrotowego» działania” (Karwat 2001, s. 40, 42). wiązań ${ }^{3}$. W odróżnieniu od jawnej represyjności dominującej w latach pięćdziesiątych normalizatorzy wybrali raczej narzędzia charakterystyczne dla przemocy symbolicznej, nie dbając zbyt stanowczo o to, czy zideologizowany propagandowy przekaz rzeczywiście - na poziomie podmiotowej interioryzacji - dociera do zakładanego adresata, wzbudzając w nim pożądany polityczny entuzjazm ${ }^{4}$. Konsekwencją udziału w tej rozgrywce okazuje się egzystencjalny i etyczny paraliż, gdyż system, który toleruje, by nie powiedzieć wspomaga konformizm, hipokryzję i kunktatorstwo, „w nagrodę” pozwalając na zaspokajanie materialnych potrzeb $\mathrm{i}$ - niewątpliwie wbrew założeniom doktryny - wspierając konsumpcyjny „drobnomieszczański” habitus, rodzi, jak w głośnym eseju-manifeście Siła bezsilnych gorzko konstatuje, unikający skądinąd terminu „normalizacja” i zastępujący go bardziej uniwersalnym określeniem ,,posttotalitaryzm”, Havel:

Głęboki kryzys ludzkiej tożsamości, wywołany przez życie w kłamstwie i na zasadzie sprzężenia zwrotnego życie to umożliwiający, niewątpliwie ma też wymiar

\footnotetext{
${ }^{3}$ Zdaniem Hanny Gosk: „Na porządek rzeczy decydujący o tym, iż daną wersję rzeczywistości (oraz właściwą jej kulturę) żyjąca w niej społeczność uznaje za normalną, naturalną, składa się wszystko to, co trzeba wiedzieć czy też, w co trzeba wierzyć, aby postepować w sposób akceptowalny dla członków tej społeczności w ramach ról pełnionych przez każdego z nich. [...] Normy wyznaczają ideały (reguły) właściwego zachowania się w określonych sytuacjach, w odniesieniu do innych jednostek społeczności, w której istnieje określona zgoda co do określonych standardów zachowania. Ci, którzy nie przestrzegaja ustalonych reguł, są marginalizowani, naznaczeni innością, wykluczani” (Gosk 2008, s. 27).

${ }^{4}$ Por.: „Politická rovnováha byla dosažena podvolením se požadavkům soukromé sféry a rezignaci na jakoukoliv snahu mobilizovat občany k budování socialismu. Zvyšující se životní úroveň byla propagována jako úspěch socialismu. Díky prosazení hmotného blahobytu jako symbolu životního naplnění se podařilo utlumit zájem o politické či ekonomické alternativy k stávajícímu systému, což přineslo normalizačnímu režimu neobyčejnou stabilitu. Oficiální komunistická kultura přestala od 70. let propagovat národ dychtivých, veřejně aktivních komunistů. Namísto toho se snažila vytvořit národ soukromých osob spojených dohromady společnou snahou o materiálně kvalitní život, což měl nejlépe umožnit právě komunistický režim” (Machek 2010, s. 11)
} 
moralny: przejawia się między innymi jako głęboki kryzys moralny społeczeństwa. Człowiek uznający konsumpcyjną skalę wartości, „roztopiony” w amalgamacie cywilizacyjnej stadności i nie związany z porządkiem bytu poczuciem odpowiedzialności większym od odpowiedzialności za utrzymanie się przy życiu - jest człowiekiem zdemoralizowanym. System opiera się na tej demoralizacji, pogłębia ją, jest jej społeczną projekcją (Havel 2001, s. 93).

Postawa Foustki, uwikłanego w ,szatańskie” machinacje Fistuli (w zakończeniu dramatu zdemaskowanego jako ,tajny agent” zwierzchników sprawdzających lojalność protagonisty) i w efekcie po kolei zdradzającego wszystkich dotychczasowych sojuszników, znakomicie zaś ilustruje ów, warunkowany instynktem samozachowawczym imperatyw „utrzymania się przy życiu”, w którym Havel dostrzega znamiona posttotalitarnej systemowej moralnej degrengolady.

Nie zawsze jednak dramatopisarz skłonny był do stawiania tak radykalnych oskarżeń, kierowanych zresztą zarówno pod adresem reżimu, jak i jednostek, zbyt łatwo poddających się operacjom korupcyjnej socjotechniki. W znanej jednoaktówce Audience (Audiencja, 1975), której ironiczny tytuł dotyczy rozmowy literata, Ferdinanda Vaňka, zdegradowanego po normalizacyjnych czystkach do roli niewykwalifikowanego robotnika $\mathrm{z}$ dysponujacym moca decydowania o losie podwładnych majstrem, który, zirytowany niezłomnym, przynajmniej na pierwszy rzut oka, pryncypializmem swego interlokutora, zarzuca mu, motywowane swoistym „egoizmem czystego sumienia”, zakłamanie, skutkujące atrofią wrażliwości na krzywdę drugiego człowieka:

No vy! Inteligenti! Páni! To jsou jen samy hladký řečičky, jenomže vy si to můžete dovolit, protože vám se nic nemůže stát, o vás je vždycky zájem, vy si to vždycky umíte zařídit, vy jste nahoře, i když jste dole, zatímco obyčejnej člověk se tady plahočí a má z toho prd a nikde se nedovolá a každej se na něho vysere a každej s ním zamete a každej si ne něho houkne a život žádnej nemá a nakonec ještě o něm páni řeknou, že nemá principy! Teplej flek ve skladu, to bys ode mě vzal - ale vzít si i kousek toho svinstva, v kterým si musíme denně brodit, to už se ti nechce! (Havel 1992, s. 228).

Przeciwstawienie ,życia w kłamstwie” (zdrady kardynalnych wartości) i ,życia w prawdzie" (wierności ideałom) stanowiące, w opinii
Havla, konstytutywny wyznacznik posttotalitarnych światopoglądowych polaryzacji, zyskuje w ten sposób nieco odmienną, mniej pod względem etycznej ortodoksji rygorystyczną, wykładnię, bliższą w gruncie rzeczy coraz śmielej w literaturze czeskiej - również oficjalnie publikowanej - pojawiających się sygnałów zaniepokojenia obserwowanym rozchwianiem powszechnie dotąd respektowanych paradygmatów aksjologicznych ${ }^{5}$. Od końca lat siedemdziesiątych bowiem na czechosłowackim rynku wydawniczym zaczęły pojawiać się teksty zrodzone, jak to określa Vladimír Papoušek ,z odmítavé reakce na dobovou preferenci tematických a ideologických kritérií" (Papoušek 2008, s. 511). Ich autorzy

[...] programově hledající autenticitu přítomnosti [...] v podstatě akceptovali limity, které jim bránily naplno zachytit vztah mezi soukromým individuálním životem a charakterem společnosti, w níž je tento život žit, a snažili se svou výpověd’ omezit na sféru bezprostředních, osobních zážitků a zkušeností (Papoušek 2008, s. 511).

Za patronów tej czeskiej wersji „literatury moralnego niepokoju” najczęściej uważa się Bohumila Hrabala i Vladimíra Párala, którzy, w odmienny sposób i na podstawie zróżnicowanych motywacji już w latach sześćdziesiątych dążyli w swej twórczości do ukazania współczesnej codzienności w jej fascynującym niezwykłością (Hrabal) lub przerażającym automatyzacją stereotypowych zachowań i atrofia „wyższych" uczuć (Páral) wymiarze. Ten zwrot w stronę reprezentacji powszedniej egzystencji w literaturze balansującej na granicy cenzorskiego imprimatur $\mathrm{w}$ pierwszym rzędzie zaowocował zainteresowaniem sfera prywatnego życia, w której, bez wikłania się w ryzykowne i w realiach „kultury reglamentowanej” de facto niedozwolone, ideologiczne debaty, dopuszczalne okazały się, ostrożnie formułowane, elementy krytyki społecznej, nierzadko powiązane z aktualizacją motywu konfliktu generacyjnego, tradycyjnie już, przynajmniej od czasów romantyzmu, otwierającego przestrzeń dla rozważań dotyczą-

5 Świadectwem tych dążeń pozostaje wydana w 1982 roku monografia Jana Lukeša Prozaická skutečnost (por. Janoušek 1996). 
cych zdrady autentycznych wartości ${ }^{6}$. Spór ,synów” z ,ojcami”, choć w ujęciu prozaików publikujących oficjalnie w przeważnej mierze znajdujący ,katharsis” w koncyliacyjnym czy raczej kompromisowym przełamaniu młodzieńczych rozterek, pozwalał jednak na wyeksponowanie, oczywiście w sposób zakamuflowany i dzięki korzystaniu z rozmaitych strategii ,ezopowego” zapośredniczenia, mankamentów „późnosocjalistycznej” rzeczywistości, oferującej wkraczającemu w dorosłość pokoleniu jedynie „stracone złudzenia”, wypływające z zadekrekretowanego przez system przymusu bezwarunkowej akceptacji panujących stosunków społecznych ${ }^{7}$. Vladimír Páral, od początku swej twórczości nieukrywający jej intertekstualnych koligacji z pisarstwem Balzaka, a w latach siedemdziesiątych usiłujący, zresztą za cenę poważnych etycznych ustępstw, zachować resztki (bądz: pozory) swobody kreacyjnej, ów zanik egzystencjalnych iluzji ilustruje, prezentując ,egzemplarycznie skonfigurowane” biografie bohaterów kolejnych powieści (Generální zázrak. Román naděje; „Cud generalny. Powieść nadziei” - 1977, Muka obraznosti; „Udręki wyobraźni” - 1980):

${ }^{6}$ Por.: „Jednu z linií oficiální české prózy sedmdesátých a osmdesátých let tvořily prózy autorů, zpravidla mladých, kteří se pokusili - byt' ne vždy přesvědčivě - o vyslovení generačního pocitu, případně i o ideologicky neortodoxní výpověd' vyjadřující nesnadné hledání základních hodnot, axiomů a konstant lidské existence. Tyto prózy se obracely především k problematice soukromé, ke sfére mezilidských vztahů, a osobních zážitků" (Papoušek 2008, s. 511). Na początku lat osiemdziesiatych konflikt pokoleniowy najbardziej przenikliwie przeanalizował Radek John w bestsellerowej powieści Džinový svět (,Jeansowy świat”; 1980).

${ }^{7}$ Por.: „Při dobovém hodnocení takových próz hrálo významnou roli, jak byla integrace mladých do většinové společnosti jednotlivými autory hodnotově pojímána. Pro normalizátory bylo důležité, aby takovéto prózy potvrzovaly oficiálně hlásanou tezi, že v socialismu je prostor pro všechny a mezigenerační střety jen důsledkem nevyzrálostí mladých, kteří časem pochopí, kde je jejich místo a zařadí se. Ti, kteří se snažili v rámci oficiálního kontextu vůči tyto tezi vymezovat, naopak oceňovali, když autor tematizoval i složitost a problematičnost světa, do něhož by mladí hrdinové měli zapadnout" (Papoušek 2008, s. 510).
S telecím nadšením jsem sem před sedmí lety dorazil prrímo z fakulty a bylo řečí, slibů a stisků ruky jak př́i volbách prezidenta USA. Tímto mumrajem náležitě zblbnut, zážral jsem se do práce jako naposledy asi Balzac nebo Tomáš Alva Edison, s mým laborantem Leošem Jermanem jsme dřeli patnáct hodin denně [...] a po třech letech se nám kupodivu povedla veliká věc (československý patent a hezkých pár miliónů pro fabriku), až př́lišs veliká ... protože $\mathrm{z}$ těch miliónů mělo připadnout nám necelých šedesát tisíc. [...] Nakonec jsme dostali svou odměnu. Tat'kové se tvářili, jako by šla z jejich vlastní kapsy, a dali ji jako cukr pejskům, kteří jim ted' budou hezky papat z ruky a hezky ji lízat... Kdykoliv jsem ochoten znovu tvrdě pracovat zas třeba patnáct hodin denně, ale hrbit se ani vteřinu. Čímž jsem upadl v trvalou nemilost - i oni u mě a odňali mi laboranta Leoše. Já jim odňal sebe. Nakládám s sebou výhradně sám dle svého osobního plánu řízeného životem sebevelitele (Páral 1989, s. 9-10).

Choć podobne deklaracje ,ppostawy buntowniczej” mogły w ,znormalizowanej" literaturze pojawiać się wyłącznie jako część składowa pejoratywnego portretowania postaci, to jednak pozwalały na przemycanie niewygodnych treści, korespondowały bowiem z charakterystycznym dla społecznej atmosfery późnego socjalizmu doświadczeniem ,zakleszczenia się” w świecie, w którym dominują rutyna, monotonia i nuda, a brak egzystencjalnych i/lub zawodowych perspektyw rodza poczucie wypalenia, wycofania się z indywidualnych tożsamościowych projektów i w ostatecznym rozrachunku - wyjątkowo przez reżimowe antropologiczne wyobrażenia o „prawidłowym” stosunku do rzeczywistości tępionej - alienacji. Wrażenie zastoju, swoistego utknięcia w sieci niezmiennych, na zawsze w aktualnie przeżywanym kształcie ustabilizowanych politycznych rozwiązań, powodowało zaś, że, jak to po latach zrekapitulował Pavel Janoušek:

Z našeho jednání se vytratila př́tomnost jako spočinutí a trvání. Čas není pouze kategorie astronomická, ale i společenská, sémantická a především psychologická Bezmála dvacet let charakterizoval náš život pocit absence dějin. Historie jako by skončila s př́chodem Bratrů, respektive s následnými prověrkami, budoucnost pak byla nejasná a málokdo věřil, že $\mathrm{v}$ ní dojde $\mathrm{k}$ pronikavým změnám. Bytí běžného Čecha bylo uzavřeno do pozvolna plynoucí každodennosti, která se omezovala výhradně na soukromé události. Události veřejné, politické a společenské se odehrávaly kdesi daleko a jako by neměly bezprostřední dopad. $V$ prítomnosti se tak nemohlo stát nic mimořadného, co by zásadně ovlivnilo její kvalitu (Janoušek 2001, s. 88$)^{8}$.

8 Jeszcze dobitniej to przeświadczenie o „końcu historii”, określającym „normalizacyjne” poczucie (bez)czasu, sformułował Kamil Činátl: „Komunistická ideo- 
Pesymistyczne odkrycie, że ,osiągnięto już wszystko, co było do osiągnięcia”, a potencjalnie dostępne modyfikacje tego dorobku polegać mogą jedynie na pomnażaniu dóbr materialnych (symbolizowanych triadą ,mieszkanie - samochód - dacza”), ewentualnie na zdobywaniu wyższej pozycji zawodowej, z jednej strony powodują niemożność przezwyciężenia marazmu, z drugiej strony zaś budzą nieokreślone oczekiwania i nadzieje:

Na východě se začalo objevovat studené slunce jako příslib pěkného počasí, pěkného dne a jara, na které už všichni (...) čekali, aniž by věděli proč, aniž by mohl doufat, že jim přinese něco lepšího, světlejšího, aniž by mohli doufat, že vyřeší jejich problémy, ale oni přesto čekali a možná jenom někde u dna vědomí si byli ochotn připustit, že čekají proto, že se něco opravdu změní, i kdyby se nestalo vůbec nic, alespoň se změní roční období. A někdy i taková změna může být událostí (Zapletal 2001, s. 116).

Słowa te pochodzą z, uznawanej za najważniejszy głos „rozczarowanego pokolenia", powieści Zdeňka Zapletala Půlnočni běžci („Biegacze o północy”; 1986), próbującej - na przykładzie „modelowej” rekonstrukcji losów mieszkańców pewnego czeskiego miasteczka nazwanego - na zasadzie generalizującej toponimicznej metafory Městec (jego pierwowzorem był południowomorawski Holešov), opisać ów stan „duchowej atrofii”, która w osiemdziesiątych latach zmusiła twórców (od pisarzy i dramaturgów po scenarzystów sławnych czechosłowackich seriali, które same w sobie stanowiły wówczas specyficzny fenomen kulturowy interpretowany dziś chętnie w kategoriach zaproponowanego przez Antonio Gramsciego kategorii ideologicznej hegemonii ${ }^{9}$ ) do zdiagnozowania sytuacji i zaproponowania

logie padesátých let širíila optimistický étos budování ráje na zemi. V konfrontaci s touto radostnou zvěsti o novém člověku a novém světě nabízí normalizačn ideologie suchoparné poučení z krizového vývoje. Diskurz poučení není na rozdíl od diskurzu budování a boje orientován na budoucí utopii, ale obrací se do minulosti. Normalizační společnost má legitimizovat nikoliv cíl (komunistický ráj na zemi), ale zkušenost již uzavřených bojů. Tento důraz na poučení z minulost vtiskl normalizaci punc stáŕí" (Č́inátl 2010, s. 183)

${ }^{9}$ Jak pisze Jakub Machek: „Komplexita a rafinovanost významů zakódovaných do televizního textu má významný účinek na diváky. Různorodé kódy díky své konzi- dróg wyjścia z kryzysu. Zapletal, prowadząc dość przejrzystą grę z cenzura i jednocześnie budując, poniekąd „między wierszami”, płaszczyznę porozumienia z poszukującym we współczesnych fabułach znaków aluzyjności, czytelnikiem ${ }^{10}, \mathrm{z}$ jednej strony wpisywał swoją powieść, traktowaną, o czym świadczą liczne, wplecione w tekst quasi-publicystyczne wtręty, jako sui generis raport o stanie świadomości zbiorowej ${ }^{11}$, w tradycję prozy małomiejskiej (z definiującym jej aksjologiczne podglebie atakiem na drobnomieszczańską mentalność ${ }^{12}$ ), z drugiej strony zaś, by decydentów polityki kulturalnej uspokoić, przypominał ideały, które niegdyś przyświecały budowniczym

stentnosti poskytují jednotný soubor významů sloužících k udržení, legitimizaci a naturalizování dominantní ideologie. Populární televizní program je komplexně a hluboce naplněn ideologií. [...] Tehdejší televizní seriály díky své popularitě proto divákům nabízely každodenní návod, jak rozumět okolnímu světu, pomáhaly naturalizovat požadované významy, hodnotový systém, stejně jako modely a vzory jednání vhodné k bezproblémovému životu v reálném socialismu" (Machek 2010, s. 16).

${ }^{10}$ Jak przypomina Pavel Janoušek: „Zpočátku nevědomě, od šedesátých let však zcela záměrně se česká literatura podílela na rozkladu režimu, který se ji i celou společnost snažil spoutat ideologickými normami. Aniž bychom př́liš přeceňovali sociální a podceňovali estetickou funkci umění, aniž bychom přehlíželi existenci množství autorů, kteří svými výplody pomáhali nastolit a oslavit daný sociálně-politický stav nebo jej alespoň petrifikovali, přece jen si musíme uvědomit, že dobrá literatura v Čechách dlouho vznikala a byla přijímána s vědomím, že si autor musí »něco « troufnout a že kvalita je tam, kde se odváží pojmenovat něco, o čem by se mělo mlčet, nebo tam, kde použije tabuizované formy" (Janoušek 2001, s. 86-87).

${ }^{11}$ Por.: „Vypravěč s oblibou [...] pracuje s hromadnými údaji reprezentujícími československou sociální a ekonomickou realitu (ceny převáděné na pracovní dobu nutnou při průměrné mzdě atd.). Je obecné v povaze modelu, že si nějak definuje své okolí; tady shrnují naznačené průřezové sociologické charakteristiky realitu za městeckými branami. [...] Řeč vševědoucího vypravěče je záměrně velmi neutrální, velmi neosobní, s významně zvýšenou frekvencí výrazů obsahujících v sobě moment opakovanosti, všeobecnosti” (Janáček 1993, s. 333).

${ }^{12}$ Mentalność ta staje się, przedmiotem przedstawienia w debiutanckiej powieści Michala Viewegha Názory na vraždu („Poglądy na morderstwo”; 1990): „Podle návodů v Praktické ženě paní Čuřínová nejen šije, plete a vaří, ale provadí i nejrůznější 
„,nowego sprawiedliwego świata”, teraz jednak zostały zapomniane czy zastąpione obojętnością i „stadnym egoizmem”:

Čas a události se valily kolem nich a oni, když je museli zaznamenat, jim nevěnovali žádnou pozornost. Měli své společné vědomí, které je chránilo jak vrstva tuku před vším, co se dělo vně jejich mikrosvětů. [...] Obyvatelé Paneláku 66 neměli vlastní názory. Na nic. Jejich názory se formovaly z nezaručených informací a hospodských keců, neopodstatněných klepů a $\mathrm{z}$ přebraných a přežvykaných názorů někoho, koho pokládali ve svém okolí za moudrého nebo toho, kdo do toho vidí. Jejich názory nebyly pevné a nezávisle na čase se měnily. Jejich názory měly hodnotu kukaččina mateřství. [...] Mlčeli, když třeba bylo něco říct, a do ničeho se nemíchali. Někteř́ z nich, aby zajistili dětem pohodlnou budoucnost, ustoupili až na pokraj, aniž by mysleli na to, že děti jednou vyrostou a v té době, kdy si děti o dospělých nic dobrého nemyslí, budou si jejich děti myslet o nich jenom to nejhorší. Takoví byli. Přikrčení, ale spokojení. A v jejich genech byly zakódovány dávné zkušenosti pralidí, dávná sdělení husitů, kolaborantů, stavitelů velkých děl, velkých revolucionářů a taky informace věčných měštáků a pseudodohlížitelů nad morálkou, dávné odkazy dobročinnosti a taky poníženosti, vychytralosti a zbabělosti a jejich opravdovým a jediným hř́íchem byla nevědomost (Zapletal 2001, 139-141).

Zapletal zdaje się zatem podzielać pogląd, że „za podstawowe źródło amoralizmu może być uznana nieznajomość natury moralności” (Frydrych 2014, s. 127) ${ }^{13}$. Jednakże, nawet jeśli, obdarzeni (w odróżnieniu od mieszkańców bloku nr 66) instynktem etycznym prota-

drobná vylepšení své domácnosti. [...] Nedávno si takto zhotovila rozlišovače elektrických šňůr; v souladu s návodem opatřila konce šňůr různobarevnými plstěnými kroužky, na které pak ještě pro jistotu vyšila jméno př́íslušného spotřebiče. A od té doby paní Čuř́nová, neschopná rozeznat podstatné od malicherného, moudré od hloupého, a zásadové od nemorálního, bezpečně rozlišuje rádio, mixér, ledničku a remosku - a nikdy se nesplete" (Viewegh 1996, s. 117-119). Należy przy tej okazji podkreślić, że krytyka drobnomieszczaństwa, jako negatywny punkt odniesienia, stanowiła stereotypowy temat socjalistycznej utopii budowy nowego człowieka. Pozostałości „filisterskich nawyków”, chętnie przypominane przez autorów prozy generacyjnej, pełnią zatem w ich tekstach funkcję demaskatorską: pokazują niepowodzenia reżimowej propagandy.

${ }^{13}$ Autor tych słów, J. Frydrych przyznaje też, a jego konkluzje korespondują z diagnozą ,etycznego analfabetyzmu”, o który Zapletal oskarża ,znormalizowane” społeczeństwo, że: „Amoralista odrzuca nie tyle moralność, jako określony sposób goniści dzieła - określani za pomocą swych zawodowych ról, co eksponuje ich społeczną typowość, młodzi inteligenci: Doktor i Inżynier, sfrustrowani (by nie powiedzieć: zniesmaczeni) zakresem własnego konformizmu decydują się na zastosowanie skromnych (zamkniętych w granicach systemowej aprobaty) środków naprawczych, to ich działania albo spełzają na niczym, albo - podane w formie, kompromisowej zresztą i niezwykle ostrożnej, moralistycznej maksymy - dowodzą swej nieprzystawalności do wymogów praktycznej egzystencji, głęboko uzależnionej od powszechnie panującej zgody na nieetyczność postępków, zachowań i - w efekcie - całego stylu życia:

Údržbář stále přemýšlel o tom, co mu řekl Doktor [...] a taky si vzpomínal, jak to Doktor objasnil. - Je potřeba být odvážný, moudrý a smíŕlivý. [...] Moudrý, abys věděl, co můžeš, na co máš, aby ses dokázal odhadnout a ocenit. Smírlivý, aby ses smíril s tím, že některé věci prostě nenapravíšs, at' děláš cokoliv, a odvážný proto, abys proti těm věcem, na které síly máš, přece jen dokázal bojovat. [...] Ale já jsem to vymakal... Moudrý, abys dělal jenom to, co musíš, a tolik, kolik musíš. Odvážný, aby ses nebál, a něco si užil a na něco si přišel bokem, a smíŕlivý, abys pochopil, že s tím vším vůbec nic nenaděláš, rozchechtal se Údržbáŕ (Zapletal 2001, s. 285-286).

W tak zdiagnozowanej, beznadziejnej, jak się wydaje, sytuacji, bohaterom pozostaje jedynie owo tytułowe „,ieganie o północy”, odczytywane, w myśl motta przejętego z dramatu E. L. Doctorova Drinks before Dinner („Drinki przed obiadem”; 1978), jako metafora ucieczki przez przewidywaną globalną katastrofą (w powieści wielokrotnie powraca temat zagrożenia wojna atomowa), ale też - w głębszych warstwach semantycznych tekstu - odzwierciedlające dialektyke moralnych „wzlotów i upadków”, która lokalizuje życie w socjalistycznej „znormalizowanej” duchowej próżni w przestrzeni swoistej

swojego istnienia, ile pewne jej rozumienie, a wynikiem tego jest faktyczne nieuwzględnianie moralnych punktów odniesienia. To, co jest nieznane, czego nie można doświadczyć i zrozumieć, faktycznie nie może mieć dla człowieka znaczenia. W przypadku amoralizmu można mówić o pewnego rodzaju defekcie natury epistemologicznej, który uniemożliwia amoraliście doświadczenie i zrozumienie tego, czym jest moralność" (Frydrych 2014, s. 127) 
etycznej nierozstrzygalności ${ }^{14}$. Co ciekawe, w repertuarze intersemiotycznych odniesień, precyzujących moralistyczne przesłanie powieści, pojawiają się również „faustyczne” reminiscencje (być może w zakamuflowany sposób odsyłające do ich Havlowskiej interpretacji), wyraźnie, mimo że Zapletal posługuje się w tym przypadku, zrozumiałymi dla odbiorcy, niedomówieniami, kojarzące się z ,diabolicznymi" machinacjami, które pozwalają systemom (post)totalitarnym wtłaczać jednostkę ludzką w tożsamościowe schematy, skutkujące jej nieodwracalnym zniewoleniem i dobrowolną nierzadko zdradą, teoretycznie nadal wyznawanych, etycznych aksjomatów:

Inženýr jim tentokrát promítl na videorekordéru mad’arský film Mefisto, natočený podle literární předlohy Klause Manna. [...] Potom si povídali, inspirovaní filmem, který shledli a skutečnými událostmi svých životů (Zapletal 2001, s. 343).

Ożywienie ,archetypowych” narracji, z jednej strony służące ich uwspółcześnieniu i polemicznej najczęściej aktualizacji, z drugiej strony natomiast - eksponujace ponadczasowy semantyczny potencjał zakorzenionych w kulturowej pamięci fabuł i powiązanych z nimi „figur zbiorowej wyobraźni” - okazuje się dogodnym narzędziem także dla Vladimíra Macury, który w powieści Občan Monte Christo („Obywatel Monte Christo”; 1981, pierwsze wydanie: 1993) splata historię wyrafinowanej zemsty za małżeńską niewierność (temat skądinąd zastanawiająco „nadobecny” w narracjach dotykających problemu ,zdrady ideałów”) z politycznymi uwarunkowaniami, odpłate taka ułatwiajacymi czy wręcz umożliwiającymi (por. Janoušek 2014 , s. 265 $)^{15}$. Bohater dzieła, Petr Lambda, pracownik wydziału teorii literatury Czechosłowackiej Akademii Nauk, wykorzystuje bo-

${ }^{14}$ Por.: „Rozběhl se, aby dohonil Barona a Inženýra, rozběhl se a běžel po sestupné křivce sinusoidy, žeby se dostal až na její dno, a potom se s námahou dra zpátky nahoru, aby stoupal a padal, a řídil se citlivým řídicím centrem v sobě, které registruje změny a určuje nový směr, ale nepočítá oběti, následky a ztráty" (Zapletal 2001, s. 404-405).

${ }^{15}$ Jak bowiem dowodzi Mirosław Karwat: „Intrygant najlepiej pożywi się tam, gdzie panuje »duszna« dwuznaczna atmosfera. $Z$ natury swojej »łowi ryby w metne wodzie«. Najlepiej czuje się [...] w sytuacji powszechnego i wzajemnego zakłamania wiem swą zawodową pozycję i dogłębną znajomość profesjonalnego środowiska, by kochanka żony, uznanego „reżimowego” poete, Vlastimila Šerhofra, otoczyć atmosferą podejrzeń skoncentrowanych wokół domniemanych, podejmowanych poza kontrola władz, kontaktów rywala z zachodnimi dyplomatami. Wielotorowo zaprojektowana intryga, w której „wszystkie chwyty są dozwolone”, a protagonista nie waha się posługiwać plotką, donosem, sfałszowanymi dokumentami, a nawet maska i przebraniem, w warstwie fabularnej powieści kończy się fiaskiem (usunięty ze stanowiska Šerhofr zostaje przełożonym bohatera) i ostateczną moralną kapitulacją nieudolnego naśladowcy sławnego Dumasowskiego mściciela, na poziomie metaliterackim wyjaśnionymi ingerencją „,bóstwa” zwanego przez Lambdę ,,Wielkim Epikiem", a zatem niezbywalnością działania przypadku zdolnego od wewnątrz zdemontować każdy, nawet najbardziej precyzyjnie skonstruowany plan ${ }^{16}$. Ironia losu decyduje zatem o rezultatach zabiegów manipulacyjnych, u ich podłoża leży bowiem (naiwne?) przeświadczenie o stricte racjonalnej, opartej na nienaruszalnych zasadach „żelaznej logiki”, budowie rzeczywistości, w której odpowiednio „spreparowana" przyczyna bezwarunkowo wywołać musi przewidziany skutek. „Wielki Epik” zaś odgrywa w powieściowej fabule rolę „kontrintryganta” (nieosobowego - co prawda - i działającego na zasadzie ,ślepego trafu”), wprowadzanego, jak przypomina Peter von

w stosunkach międzyludzkich. Bezbłędnie i niezawodnie potrafi wykorzystać niewzajemność i nieszczerość w więzach przyjaźni, miłości, koleżeństwa, dwuznaczność i niewzajemność sojuszy między silniejszymi i słabszymi, ukrytą rywalizację osób bliskich i wspólników w interesach. [...] Bez wahania wbija swój klin, gdy tylko zauważy, że w danym kręgu deklaracje i gesty są równie puste jak gorliwe, zasady i zobowiązania równie święte jak... uciążliwe i niewygodne" (Karwat 2001, s. 46).

${ }^{16}$ Por.: „Velký Epik (posvět' se jméno jeho) nedopouští, aby si život lidský plynul jen tak, od A do Z, jak si kdo umane a naplánuje. Velký Epik miluje literární stavbu lidských curriculum vitae, zbláznil se do odboček a nečekaných point, okulista musí přijít o oko a láska, po níž jsme prahli, nás pak hladí k vyhlazení. [...] Jenže [...] nejméně ze všeho má Velký Epik rád své věrné apoštoly, nesnáší, když mu nahlížeji do karet a odmítají se nechat překvapit. Velký Epik krvelačně křižuje vlastní vyznavače" (Macura 1993, s. 76). 
Matt, „by krzyżować szyki zaplanowanej na wielką skalę strategii” (Matt von 2009, s. 69), co, kontynuuje badacz, ,nieuchronnie zmierza do powstania opozycji o charakterze moralnym" (Matt von 2009, s. 69) i owocuje osiągnięciem stanu anagnórisis, który

[...] nie tylko powoduje dramatyczne zagęszczenie akcji, ale także rzuca jaskrawe światło na centralne kwestie etyczne, na ostateczne rozstrzygnięcia między dobrem a złem, definitywne podziały na dobrych i złych. [...] Intryga zawsze i wszędzie stanowi inscenizację etyki i moralności, konfrontuje nas z ostatecznymi pytaniami, o to, co jest prawem, a co bezprawiem. [...] Dlatego anagnórisis, a więc oczekiwana, pożądana, budząca strach chwila prawdy,bardzo często przeradza się w regularny osąd i wydanie wyroku, a nawet jego wykonanie (Matt von 2009, s. 100).

W Macurowskiej wizji znormalizowanej socjalistycznej rzeczywistości, podobnie jak w większości ,diagnostycznych” powieści z lat osiemdziesiątych, podziały na dobro i zło tracą w wielkiej mierze rację bytu, wszyscy bohaterowie funcjonują bowiem w szczególnej „szarej strefie” etycznej nieokreśloności i wszyscy godzą się na zamianę swej prawdziwej, zanurzonej w autentycznie przeżywanym uniwersum wartości, egzystencji, na „życie zastępcze”, które służy, w proroczym niemal opisie Ivana Vyskočila, aby

[...] jim (vlastníkům) pomohl dosáhnout a dosahovat toho, co mají, čeho si cení, že jím (tím životem) mají určitou váhu. [...]Že jim umožňuje vlastnit něco, co jim není vlastní. Tedy něco, co jim je cizí, nebo čím jsou si cizí. [...] Žijí pomocný život místo vlastního života. Je to asi otázka pravdy, pravdivosti a hodnověrnosti. A není tak, že pomocným životem se z člověka stává „něco” („Hled”, aby z tebe něco bylo!”), vlastním životem „někdo”? Je si blízký, je si osobní, patří si. I druhým a světu (Vyskočil 1993, s. 14).

Czescy pisarze ostrzegający przez katastrofalnymi skutkami takiej „zdrady autentyczności” pokazują zaś, jak łatwo maska przekształcić się może w drugą twarz i jak często hołdowanie pozornym profitom wiedzie ku zatraceniu etycznego horyzontu, a zatem i ku rezygnacji z własnego człowieczeństwa. Po przekroczeniu niektórych granic nie ma już bowiem odwrotu.

\section{Literatura}

Č i ná 1 K K., 2010, Časy normalizace, [w:] Tesilová kavalérie. Popkulturní obrazy normalizace, red. P.A. Bílek, B. Činátlová, Př́ibram, s. 166-187.
Frydrych J., 2014, Anatomia amoralizmu - na podstawie opowiadania André Gide'a »Immoralista«, [w:] Etyka i literatura. Antologia tekstów, red. A. Głą, Lublin, s. 105-132.

G o s k H., 2008, Poczatek. Powojenna rzeczywistość w polskiej prozie lat czterdziestych XX wieku, [w:] (Nie)ciekawa epoka? Literatura i PRL, red. H. Gosk, Warszawa, s. 13-51.

H a v e 1 V., 1992, Hry, Praha.

H a vel V., 2001, Sita bezsilnych, przeł. P. Godlewski, [w:] Hrabal, Kundera, Havel... Antologia czeskiego eseju, red. J. Baluch, Kraków, s.67-153.

J a n á č e k P., 1993, Zděněk Zapletal: „Půlnoční běžci«, [w:] Český Parnas. Vrcholy literatury 1970-1990, red. J. Holý, Praha, s. 330-336.

J a n o u š e k P., 1996, Spor o Lukeše. Kapitola z české literárni kritiky počátku osmdesátých let, [w:] Normy normalizace, red. J. Wiendl, Praha-Opava, s. $82-90$.

J a n o u š e k P., 2014, Ten, který byl. Vladimír Macura mezi literaturou, vědou a hrou. Úvod povahopisný, Praha.

J a n o u š e k P., 2001, Time-out aneb Mé kritické pokusy blaboly a omyly z let 1987-1999, Brno.

J a n o u š e k P., 1996, Spor o Lukeše. Kapitola z české literární kritiky počátku osmdesátých let, [w:] Normy normalizace, red. J. Wiendl, Praha-Opava, s. $82-90$.

K a r w a t M., 2001, $O$ perfidii, Warszawa.

M a c h e k J., 2010, Normalizace a populární kultura. Od domácího uměni k Ženě za pultem, [w:] Tesilová kavalérie. Popkulturní obrazy normalizace, red. P.A. Bílek, B. Činátlová, Př́ibram, s. 9-27.

M a c u r a V., 1993, Občan Monte Christo, Praha.

Matt von P., 2009, Intryga. Teoria i praktyka podstepu $w$ literaturze, przeł. I. Sellmer, A. Żychliński, Warszawa.

$\mathrm{P}$ a p o u š e k V., 2008, Různorodé podoby generačnich výpovédí o soudobém stavu světa, [w:] Déjiny české literatury 1945-1989, d. IV: 1969-1989, Praha, s. 509-517.

P á r a 1 V., 1989, Generální zázrak. Román naděje, Praha.

Poučení z krizového vývoje ve straně a společnosti po XIII. sjezdu KSČ. Rezoluce o aktuálnich otázkách jednoty strany schválená na plenárním zasedáni $v$ prosinci 1970, 1970, Praha.

P u t n a M.C.,2011, Václav Havel. Duchovni portrét v rámu české kultury 20. století. Praha.

V i e w e g h M., 1996, Názory na vraždu, Brno.

V y s k o č il I., 1993, Kosti, Praha.

Z a ple t a 1 Z., 2001, Pưlnoční běžci, Brno. 